Revista Eletrônica de Direito Processual - REDP.

Rio de Janeiro. Ano 11. Volume 18. Número 1. Janeiro a Abril de 2017

Periódico Quadrimestral da Pós-Graduação Stricto Sensu em Direito Processual da UERJ

Patrono: José Carlos Barbosa Moreira. ISSN 1982-7636. pp. 403-427

www.redp.uerj.br

\title{
A REPERCUSSÃ̃O GERAL NO NOVO CPC: A CONSTRUÇÃO DA \\ VINCULAÇÃO DA DECISÃo DE MÉRITO PROFERIDA EM REPERCUSSÃO \\ GERAL PELO STF ${ }^{1}$
}

THE OVERALL REPERCUSSIONS IN THE NEW CPC: THE CONSTRUCTION OF

THE BINDING DECISION OF MERIT IN OVERALL REPERCUSSIONS BY STF

Vinícius Silva Lemos

Doutorando em Direito Processual pela UNICAP/PE. Mestre em Sociologia e Direito pela UFF/RJ. Especialista em Processo Civil pela Faculdade de Rondônia - FARO. Professor de Processo Civil na Faculdade de Rondônia FARO. Coordenador da Pós-Graduação em Processo Civil da Uninter/FAP. Vice-Presidente do Instituto de Direito Processual de Rondônia - IDPR. Membro da Associação Norte-Nordeste de Professores de Processo - ANNEP. Membro do Centro de Estudos Avançados em Processo CEAPRO. Membro da Academia Brasileira de Direito Processual Civil - ABDPC. Membro da Associação Brasileira de Direito Processual - ABDPRO. Advogado. Recife/PE. viniciuslemos.ro@gmail.com

RESUMO: Este artigo tem o propósito de analisar o instituto da repercussão geral no novo código de processo civil, a sua relação com os precedentes obrigatórios e a correlação com as novas redações dos arts. 1.030 e 1.042 para criar uma vinculação do precedente criado em julgamento de recurso extraordinário em repercussão geral.

PALAVRAS-CHAVE: Recurso Extraordinário; Repercussão Geral; Vinculação; Precedente.

\footnotetext{
${ }^{1}$ Artigo recebido em 11/03/2017 e aprovado em 10/04/2017.
} 
Revista Eletrônica de Direito Processual - REDP.

Rio de Janeiro. Ano 11. Volume 18. Número 1. Janeiro a Abril de 2017

Periódico Quadrimestral da Pós-Graduação Stricto Sensu em Direito Processual da UERJ

Patrono: José Carlos Barbosa Moreira. ISSN 1982-7636. pp. 403-427

www.redp.uerj.br

ABSTRACT: This article has the purpose to analyze the overall repercussions in the new code of civil procedure, its relationship with the mandatory precedent and the correlation with the new writings of arts. 1.030 and 1.042 to create a binding of the precedent set in judgment of extraordinary resource in the overall repercussions.

KEYWORDS: Extraordinary Resource; Overall Repercussions; Junction; Precedent.

\section{INTRODUÇÃ̃O}

O CPC/2015 trouxe uma novel sistemática de precedentes, com a positivação do art. 926 com o dever da uniformização de entendimentos pelos tribunais, para a manutenção da segurança jurídica, com o intuito de prezar-se pela isonomia das decisões judiciais, para a manutenção de uma estabilidade, coerência e integridade na aplicabilidade dos precedentes.

Já no art. 927, o CPC/2015 especifica um rol de precedentes considerados como obrigatórios, com a necessária vinculação, quando formados, aos juízos inferiores aos tribunais que os firmaram, com claro intuito de positivar esta obrigatoriedade a uma gama de espécies decisórias que o legislador entendeu como importantes.

Neste rol estão decisões que a própria Constituição Federal já considerava como vinculantes, como a decisão do STF em controle concentrado de constitucionalidade ou a súmula vinculante, contudo inova totalmente a considerar outras decisões com tal vinculação, como: os enunciados das súmulas do Supremo Tribunal Federal em matéria constitucional e do Superior Tribunal de Justiça em matéria infraconstitucional; os acórdãos em incidente de assunção de competência ou de resolução de demandas repetitivas e em julgamento de recursos extraordinário e especial repetitivos; a orientação do plenário ou do órgão especial aos quais estiverem vinculados.

O objeto deste estudo é o fato da decisão proferida pelo STF em regime de repercussão geral não estar neste rol disposto no art. 927, com a dúvida sobre a autoridade desta decisão e a existência de sua vinculação ou não sobre os demais processos idênticos e sua força argumentativa como precedente.

\section{DA REPERCUSSÃO GERAL}




\subsection{0 instituto inserido pela emenda 2004}

O STF tem uma função da interpretação da Constituição Federal, como já vimos, contudo até pouco tempo atrás, principalmente antes da criação do STJ, abarcava também as questões infraconstitucionais, o que, de certa maneira, moldou o costume do próprio STF em julgar grandes quantidade de demandas ${ }^{2}$.

Com o intuito de aplacar essa grande quantidade de demandas e recursos no STF, a emenda constitucional $\mathrm{n}^{\circ}$. 45/2004 instituiu a repercussão geral como requisito de admissibilidade do recurso extraordinário, almejando que este fosse cada vez mais excepcional, com a possibilidade do próprio tribunal escolher e verificar quais as matérias pertinentes a seu crivo e julgamento. Parar de julgar casos meramente inter partes ${ }^{3}$, passando a portar-se realmente como uma corte de precedentes, como Marinoni ${ }^{4}$ assevera.

Há que diga que a repercussão geral substituiu a arguição de relevância, pela proximidade em termos de requisitos do próprio recurso extraordinário, contudo o critério é o inverso, já que na análise anterior, o que se tinha era a necessidade do recurso excepcional que versasse sobre questão não constitucional ${ }^{5}$ arguir uma relevância para forçar o julgamento pelo STF, o que difere da própria repercussão geral, seja pela

2 "Para a solução do problema certamente não terá trazido a mínima contribuição o caráter analítico da Constituição: quanto maior a quantidade de normas que contém, maior é naturalmente a quantidade de questões que suscita, e maior a probabilidade de que se tente submetê-las ao crivo da Suprema Corte. O problema aqui se agrava substancialmente pela formidável instabilidade do texto constitucional, objeto de dezenas de emendas ao longo de sua vigência" ASSUMPÇÃO, Hélcio Alves de. Recurso extraordinário: requisitos constitucionais de admissibilidade, in Meios de Impugnação ao Julgado Civil - estudos em homenagem a José Carlos Barbosa Moreira, Adroaldo Fabrício (coord.), Rio de Janeiro, Forense, 2007, p. 265.

3 “A criação desse requisito é, a nosso juízo, elogiável, já que faz com que o Supremo Tribunal Federal, Corte Suprema do País, só se debruce sobre causas realmente relevantes para a Nação. Não faz sentido que o Pretório Excelso perca seu tempo (e o do País) julgando causas que não tem qualquer relevância nacional, verdadeiras brigas de vizinhos, como fazia antes da EC 45/2004." CÂMARA, Alexandre Freitas. Lições de Direito Processual Civil, volume II. $14^{\mathrm{a}}$ edição, Revista e atualizada. - Rio de janeiro: Editora Lúmen Júris, 2007. p. 141.

4 “As Cortes Supremas definem o sentido da lei federal e da Constituição, agregando sentido à ordem jurídica, e apenas por isso os seus precedentes devem ser obrigatoriamente respeitados pelos juízes e tribunais. Toca às raias do absurdo elencar entre os pronunciamentos com força obrigatória as decisões proferidas em recursos repetitivos, esquecendo-se das demais decisões, inclusive das tomadas em repercussão geral pelo STF. Isso apenas teria lógica se a função das Cortes Supremas estivesse limitada a otimizar o trabalho do Poder Judiciário." MARINONI, Luiz Guilherme. A função das cortes supremas e o novo cpc. Revista Magister de Direito Civil e Processual Civil n. 65 - Mar/Abr/2015. p. 21

5 "será relevante a questão federal quando o interesse no seu desate seja maior fora da causa do que, propriamente dentro dela”. BAPTISTA, N. Doreste. Da arguição de relevância no recurso extraordinário. Editora Forense, Rio de Janeiro. 1976. p.34. 
Revista Eletrônica de Direito Processual - REDP.

Rio de Janeiro. Ano 11. Volume 18. Número 1. Janeiro a Abril de 2017

Periódico Quadrimestral da Pós-Graduação Stricto Sensu em Direito Processual da UERJ

Patrono: José Carlos Barbosa Moreira. ISSN 1982-7636. pp. 403-427

www.redp.uerj.br

imposição a todos os recursos, fato inexistente no requisito anterior, seja em recair sobre questão constitucional, não em questão federal. E, por último, a arguição de relevância era um pedido de julgamento de matéria que não era competência do STF, mas, que por existir relevância, pleiteava-se que assim fosse, almejando ${ }^{6}$, uma inclusão recursal, diferentemente da repercussão geral, a qual deve demonstrar para a Corte, que a matéria constitucional de competência natural - deve ser julgada por transcender ${ }^{7}$ a própria ação.

\subsection{A legislação no tempo: lei 2006 e o CPC/2015}

Dessa maneira, a partir de 2004, criou-se um novo requisito de admissibilidade do recurso extraordinário, a repercussão geral, porém somente em 2007 que passou a ser realmente cobrado, já que sua regulamentação ocorreu via lei infraconstitucional $-\mathrm{n}^{\mathrm{o}}$. 11.418, de 19 de dezembro de 2006 - acarretando, a partir de então, um novo requisito de admissibilidade $^{8}$. A validade prática do requisito passou a ser o dia 03 de maio de 2007, momento da aplicabilidade da regulamentação pelo Regimento Interno do STF.

A base conceitual da repercussão geral perfaz a necessidade da demonstração, pelo recorrente, da transcendência ${ }^{9}$ daquela causa para a sociedade, com impacto social, jurídico, econômico ou político. Além da Constituição Federal, em seu art. 102, § $3^{\circ}$

\footnotetext{
6 "Por sua vez, a repercussão geral é instituto que possui o objetivo de possibilitar o nãoconhecimento do mesmo recurso, caso possa não haver reflexo da referida decisão junto à sociedade. Logo, o antigo instituto buscava a inclusão, enquanto o atual justifica a exclusão, de feição bastante pragmática: uma alternativa ao congestionamento do STF." LAMY, Eduardo de Avelar. Repercussão geral no recurso extraordinário: a volta da argüição de relevância?, in Reforma do Judiciário - primeiras reflexões sobre a Emenda Constitucional $n^{\circ}$ 45/2004, coord. Teresa Arruda Alvim Wambier, São Paulo, RT, 2005. p. 178

7 De certa forma, agora a parte deve demonstrar que há relevância no seu recurso, o que, de modo antagônico, como sugere Maltez, deve comprovar que não é irrelevante: "acaba por se reduzir a uma argüição de irrelevância'. Isso porque a relevância é presumida e a irrelevância somente será reconhecida se neste sentido se manifestarem dois terços de seus membros" MALTEZ, Rafael Tocantins. Repercussão geral da questão constitucional, in Recurso Especial e Extraordinário - repercussão geral e atualidades, Rogério Licastro Torres de Mello (coord.), São Paulo, Método, 2007. p. 194

8 A natureza jurídica da repercussão seria, então, um autêntico requisito de admissibilidade, como bem asseveram Cunha e Didier Jr.: "ter que funda mentar o seu recurso em uma das hipóteses do artigo 102 , III da CF/88, terá, também, de demonstrar o preenchimento desse novo requisito."CUNHA, Leonardo José Carneiro da; DIDIER JR., Fredie. Curso de direito processual civil. Meios de impugnação às decisões judiciais e processo nos tribunais. 8 $^{\mathrm{a}}$. ed. Salvador: JusPodivm, 2012. p. 313.

9 "haverá repercussão em determinada causa/questão quando os reflexos da decisão a ser prolatada não se limita apenas aos litigantes mas, também, a toda uma coletividade. Não necessariamente a toda a coletividade (país), mas de uma forma não individual.” GOMES JR, Luiz Manoel. A Repercussão Geral da Questão Constitucional no Recurso Extraordinário. Revista Forense. 2005, p. 54.
} 
Revista Eletrônica de Direito Processual - REDP.

Rio de Janeiro. Ano 11. Volume 18. Número 1. Janeiro a Abril de 2017

Periódico Quadrimestral da Pós-Graduação Stricto Sensu em Direito Processual da UERJ

Patrono: José Carlos Barbosa Moreira. ISSN 1982-7636. pp. 403-427

www.redp.uerj.br

conceituar a própria repercussão, o art. 1.035, $\S 1^{\circ}$, determina, conceitualmente ${ }^{10}$, a

necessidade de existência de "questões relevantes do ponto de vista econômico, político, social ou jurídico que ultrapassem os interesses subjetivos do processo."

Há total subjetividade no próprio requisito, apesar da regulamentação constitucional e infraconstitucional, na tentativa de pormenorizar o instituto, contudo na aferição do mesmo, é um conceito juridicamente indeterminado, como bem pontuam Medina, Wambier e Wambier ${ }^{11}$. Desse modo, pertinente é a visualização da repercussão de matéria a matéria ${ }^{12}$, sem a existência de um regramento objetivo de auferimento deste conceito jurídico indeterminado.

\subsection{Requisito de admissibilidade prévio ou posterior?}

O STF, após a inserção da repercussão geral como requisito de admissibilidade, não julga o recurso extraordinário de qualquer processo ou demanda, mesmo diante do cabimento correto em uma das alíneas do art. 102, III da Constituição Federal, o que reforça de sobremaneira a visão de um tribunal constitucional realmente influenciante para a sociedade, como deve sempre apresentar-se judicialmente.

O recurso extraordinário perde a exclusividade de uma relevância interna para as $\operatorname{partes}^{13}$, com a necessidade da matéria recorrida suscitar questões relevantes, que impactem a sociedade ultrapassando as barreiras inter partes, com um interesse amplificado. A repercussão geral é uma admissibilidade específica, que serve como filtro para que o STF escolha o que lhe compete julgar, com uma relevância maior do que aquele

\footnotetext{
10 Marinoni critica esta conceituação, seja pelo CPC/73 ou pelo CPC/2015, do que seria a repercussão geral, insistindo que a própria constituição já define o tema de modo satisfatório e, ademais, o STF teria competente e discricionariedade para fazê-lo. "Ora, a legislação processual deve passar longe do significado de repercussão geral, uma vez que cabe apenas e unicamente ao STF dizer quando ela está presente, nos termos da norma constitucional respectiva." MARINONI, Luiz Guilherme. A função das cortes supremas e o novo cpc. Revista Magister de Direito Civil e Processual Civil n. 65 - Mar/Abr/2015. p. 21

11 "Pensamos estar-se, aqui, em hipótese típica de interpretação de conceito vago ou indeterminado" MEDINA, José Miguel Garcia; WAMBIER, Luiz Rodrigues; WAMBIER, Teresa Arruda Alvim. Breves Comentários às Nova Sistemática Processual. Civil 3. São Paula: Ed. Revista dos Tribunais, 2007. p. 242

12 "que deverá ser demonstrado pelo recorrente, cuja interpretação e conclusão acerca de sua presença são tarefas do STF, que, por meio de decisão fundamentada, reconhecerá ou afastará o requisito" ARAÚJO, José Henrique Mouta. A eficácia da decisão envolvendo a repercussão geral e os novos poderes dos relatores e dos tribunais locais. Revista de Processo, São Paulo, v. 32, n. 152, p. 185- 186, 2007. p.57

13 Comentário do autor: Não deixa de ter essa relevância, somente não há mais este ponto específico do controle difuso como a principal característica, podendo até imaginar que há uma mutação do próprio controle difuso, já que transcende ao que foi ali julgado.
} 
Revista Eletrônica de Direito Processual - REDP.

Rio de Janeiro. Ano 11. Volume 18. Número 1. Janeiro a Abril de 2017

Periódico Quadrimestral da Pós-Graduação Stricto Sensu em Direito Processual da UERJ

Patrono: José Carlos Barbosa Moreira. ISSN 1982-7636. pp. 403-427

www.redp.uerj.br

próprio processo. Não importa para o julgamento do recurso extraordinário, somente a

existência de uma questão constitucional, mas, ainda, uma relevância daquela matéria para a sociedade, a propagada transcendência material do recurso extraordinário.

Se um processo tem questão constitucional pertinente ao enquadramento ao cabimento recursal, mas não tem êxito na demonstração da repercussão geral, o recurso extraordinário, mesmo com enquadramento correto da supramencionada hipótese de cabimento, o que geraria uma irrelevância constitucional ${ }^{14}$. Uma questão constitucional pertinente somente a uma parte pequena da sociedade, ao não conter uma repercussão geral, não é julgada pelo STF.

Medina tem uma visão ímpar sobre a repercussão geral, colocando-a em dois planos: restrição de questões constitucionais a serem apreciadas pelo STF e um veículo de transposição do próprio recurso extraordinário ${ }^{15}$. Nesta visão, entende que realmente há o filtro de admissibilidade, seja para impor uma dificuldade para o próprio recurso extraordinário, mas para que o STF decida com impactos maiores para a sociedade, no outro ponto, entende que a repercussão geral seria o requisito mais importante, o que até flexibilizaria outros pontos, caso existente a repercussão, ponto que não é pacífico na doutrina $^{16}$, tampouco no STF. O entendimento é que a repercussão geral seja o último dos

14 “em princípio, qualquer situação envolvendo a aplicação de norma constitucional é de interesse público. Mas, na prática, muitas questões têm repercussão limitada às partes ou a pequeno número de casos, e há problemas reais cujas consequências são muito reduzidas, mesmo para os interessados, servindo antes como pretexto para manobras processuais protelatórias ou que visam a subtrair o mérito do litígio do direito aplicável." OLIVEIRA, Pedro Miranda de. Recurso extraordinário e o requisito da repercussão geral. São Paulo: RT, 2013. p. 293.

15 "Temos sustentado que repercussão geral opera em dois planos, em relação ao recurso extraordinário: de um lado, funciona como mecanismo de restrição das questões constitucionais que podem ser levadas ao STF; de outro, funciona como veículo de transposição de recurso extraordinário, já que, uma vez havendo repercussão geral, tende a jurisprudência do Supremo a abrandar a exigência de presença de outros requisitos do recurso.” MEDINA, José Miguel Garcia. Novo código de processo civil comentado. $4^{\mathrm{a}}$ Edição. RT: São Paulo. 2015. 948.

16 No ponto em que Medina defende que, se houver repercussão, esta seria mais importante do que os outros requisitos, com a possibilidade de gerar uma flexibilização, a pacificação é por outro entendimento. Bruno Dantas discorre sobre a controvérsia existente no passado da seguinte maneira: "De um lado, a corrente capitaneada pelo Prof. Arruda Alvim sustenta que, por se tratar de pressuposto especial (e de natureza política) do cabimento do recurso, o exame da repercussão geral deveria ser prévio ao exame de admissibilidade tradicional. De outro, autores renomados, como José Rogério Cruz e Tucci, já defenderam que a operatividade do sistema requer que repercussão geral seja examinada juntamente com os demais requisitos de admissibilidade, sob pena de sobrecarregar o plenário do STF com a análise de recursos que eventualmente não teriam chances sequer de ser conhecidos, como nos casos de falta de prequestionamento ou mesmo intempestividade." DANTAS, Bruno. Repercussão geral: perspectivas histórica, dogmática e de direito comparado: questões processuais - São Paulo: Ed. Revista dos Tribunais, 2008. p. 292-293. Contudo, o entendimento é que a admissibilidade é bipartida, com o relator analisando as questões anteriores e, somente colocando para o plenário virtual, o recurso extraordinário que seja admissível sobre os outros 
Revista Eletrônica de Direito Processual - REDP.

Rio de Janeiro. Ano 11. Volume 18. Número 1. Janeiro a Abril de 2017

Periódico Quadrimestral da Pós-Graduação Stricto Sensu em Direito Processual da UERJ

Patrono: José Carlos Barbosa Moreira. ISSN 1982-7636. pp. 403-427

www.redp.uerj.br

requisitos analisáveis ${ }^{17}$, com o preenchimento dos demais ${ }^{18}$, sejam aqueles intrínsecos ou

extrínsecos de admissibilidade.

requisitos. Conlui Dantas que: "deve ser analisada no contexto da avaliação dos requisitos de admissibilidade desse recurso, sem qualquer precedência sobre os demais pressupostos ou requisitos de admissibilidade." DANTAS, Bruno. Repercussão geral: perspectivas histórica, dogmática e de direito comparado: questões processuais - São Paulo: Ed. Revista dos Tribunais, 2008. p. 294.

17 Houve um posicionamento divergente sobre o tema, quando a então Ministra Ellen Gracie no julgamento do AI 375011, Informativo 365, minorando a necessidade do prequestionamento quando a matéria comportar a presença da repercussão geral, referindo-se à possibilidade da relativização deste requisito dependendo da importância da manifestação superior sobre a matéria de fundo. Entretanto, este posicionamento foi isolado no STF, em situação somente excepcional, como a situação do julgado analisado, não acarretando adeptos entre os demais membros do tribunal, nem da própria ministra, que defendeu por diversas vezes posteriormente, demonstrando a impossibilidade dessa relativização como regra, mas sim como possibilidade remota: 2 . Tal circunstância não constitui óbice ao conhecimento e provimento do recurso extraordinário, pois, para tanto, basta a simples declaração de constitucionalidade pelo Tribunal a quo da norma municipal em discussão, mesmo que desacompanhada do aresto que julgou o leading case. 3 . O RE 251.238 foi provido para se julgar procedente ação direta de inconstitucionalidade da competência originária do Tribunal de Justiça estadual, processo que, como se sabe, tem caráter objetivo, abstrato e efeitos erga omnes. Esta decisão, por força do art. 101 do RISTF, deve ser imediatamente aplicada aos casos análogos submetidos à Turma ou ao Plenário. Nesse sentido, o RE 323.526, $1^{\text {a }}$ Turma, rel. Min. Sepúlveda Pertence.4. Agravo regimental provido. (AI 375011 AgR, Relator(a): Min. ELLEN GRACIE, Segunda Turma, julgado em 05/10/2004, DJ 28-10-2004 PP- 00043 EMENT VOL-02170-02 PP-00362)

18 “(..) O prequestionamento da questão constitucional é requisito indispensável à admissão do recurso extraordinário.3. As Súmulas 282 e 356 do STF dispõem, respectivamente, verbis: "É inadmissível o recurso extraordinário, quando não ventilada, na decisão recorrida, a questão federal suscitada" e "o ponto omisso da decisão, sobre o qual não foram opostos embargos declaratórios, não podem ser objeto de recurso extraordinário, por faltar o requisito do prequestionamento".4. A repercussão geral pressupõe recurso admissível sob o crivo dos demais requisitos constitucionais e processuais de admissibilidade (art. 323 do RISTF). Consectariamente, se o recurso é inadmissível por outro motivo, não há como se pretender seja reconhecida "a repercussão geral das questões constitucionais discutidas no caso" (art. 102, III, $\S 3^{\circ}$, da CF).(..) Além disso, não foram opostos embargos de declaração para sanar eventual omissão, faltando, ao caso, o necessário prequestionamento da questão constitucional, o que inviabiliza a pretensão de exame do recurso extraordinário. Incide, portanto, o óbice das Súmulas 282 e 356 do STF: "É inadmissível o recurso extraordinário, quando não ventilada, na decisão recorrida, a questão federal suscitada." e "O ponto omisso da decisão, sobre o qual não foram opostos embargos declaratórios, não pode ser objeto de recurso extraordinário, por faltar o requisito do prequestionamento". A respeito da aplicação das aludidas súmulas, assim discorre Roberto Rosas: "A Constituição de 1891, no art. 59, III, a, dizia: "quando se questionar sobre a validade de leis ou aplicação de tratados e leis federais, e a decisão for contra ela'. De forma idêntica dispôs a Constituição de 1934, no art. 76, III, a: 'quando a decisão for contra literal disposição de tratado ou lei federal, sobre cuja aplicação se haja questionado'. Essas Constituições eram mais explícitas a respeito do âmbito do recurso extraordinário. Limita-se este às questões apreciadas na decisão recorrida. Se foi omissa em relação a determinado ponto, a parte deve opor embargos declaratórios. Caso não o faça, não poderá invocar essa questão não apreciada na decisão recorrida. (RTJ 56/70; v. Súmula 356 do STF e Súmula 211 do STJ; Nelson Luiz Pinto, Manual dos Recursos Cíveis, Malheiros Editores, 1999, p. 234; Carlos Mário Velloso, Temas de Direito Público, p. 236). Os embargos declaratórios visam a pedir ao juiz ou juízes prolatores da decisão que espanquem dúvidas, supram omissões ou eliminem contradições. Se esse possível ponto omisso não foi aventado, nada há que se alegar posteriormente no recurso extraordinário. Falta o prequestionamento da matéria. A parte não considerou a existência de omissão, por isso não opôs os embargos declaratórios no devido tempo, por não existir matéria a discutir no recurso extraordinário sobre essa questão (RE 77.128, RTJ 79/162; v. Súmula 282). O STF interpretou o teor da Súmula no sentido da desnecessidade de nova provocação, se a parte opôs os embargos, e o tribunal se recusou a suprir a omissão (RE 176.626, RTJ 168/305; v. Súmula 211 do STJ).” (ROSAS, Roberto, in Direito Sumular,Malheiros). (..) .” Ex positis, DESPROVEJO o agravo, com fundamento no artigo 21, § $1^{\circ}$, do RISTF. Publique-se. Brasília, 29 
Revista Eletrônica de Direito Processual - REDP.

Rio de Janeiro. Ano 11. Volume 18. Número 1. Janeiro a Abril de 2017

Periódico Quadrimestral da Pós-Graduação Stricto Sensu em Direito Processual da UERJ

Patrono: José Carlos Barbosa Moreira. ISSN 1982-7636. pp. 403-427

www.redp.uerj.br

Inegavelmente, o STF, após a inclusão do instituto da repercussão geral no

ordenamento, de certo modo, escolhe o que entende como pertinente julgar, sendo um filtro processual de admissibilidade, com uma função de, além da própria devolutividade normal, delimitar a relevância das matérias constitucionais. Uma forma de delinear-se, o que deve ser julgado, bem como, igualmente importante, do que não deve ${ }^{19}$. Demonstrando, por modo antagônico, a reflexão de que o STF debruçar-se-á, materialmente, somente em questões mais condizentes com o impacto social ao qual se espera de uma Corte Suprema, inadmitindo as que não se enquadrem a esta definição. Talamini explica isso como uma seletividade do próprio $\mathrm{STF}^{20} \mathrm{em}$ seu modo de atuação, o que, teoricamente, faz com que se aprimore as discussões realmente relevantes e os processos de competência da Corte Suprema.

\section{O JULGAMENTO DE MÉRITO DO RECURSO EXTRAORDINÁRIO COM REPERCUSSÃO GERAL}

Quando o STF realiza a decisão do recurso extraordinário de matéria com repercussão geral reconhecida, o entendimento jurídico firmado tem de ser aplicado. Mas tem um efeito vinculante? Onde tem de ser aplicado? Não há um efeito vinculante para nenhum juízo em força legal, mas causa impacto em todos os recursos extraordinários interpostos nos tribunais anteriores ao STF e que encontram sobrestados, seja em julgamento repetitivo ou não.

de abril de 2014.Ministro LUIZ FUX Relator (STF - ARE: 727284 MG, Relator: Min. LUIZ FUX, Data de Julgamento: 29/04/2014)

19 Comentário do autor: A negativa da repercussão geral, daquele recurso extraordinário sobre a matéria, causa efeitos nos demais processos, primeiramente no próprio STF, se houver recursos extraordinários com outros relatores, sobrestados ou não, estes negam seguimento, com base na ausência de repercussão geral, igualmente nos recursos extraordinários que se encontram em outros tribunais, aguardando a remessa para o STF, também serão negados em seu seguimento, inadmitindo remessa ao tribunal superior, pelos presidentes ou vice-presidentes destes tribunais, com base no artigo $1035, \S 8^{\circ}$. Neste efeito cascata, perante todos os outros recursos extraordinários que são afetados pela decisão, na ausência da repercussão geral em determinada matéria, é importante verificar-se com cuidado a coincidência das matérias recursais, tanto do recurso extraordinário analisado pelo STF, como em cada um dos demais a serem negados pelos relatores do STF e pelos presidentes ou vice-presidentes dos tribunais.

20 "Instaura-se uma atuação seletiva. Pretende-se que a restrição quantitativa confira ao Supremo Tribunal um incremento qualitativo na sua atuação. Em tese, a filtragem propiciará mais tempo e recursos humanos e materiais para a Corte dedicar não só aos recursos extraordinários que versem sobre as questões tidas por relevantes, como também para os demais processos que permanecem em sua esfera de competência." TALAMINI, Eduardo. Novos Aspectos da Jurisdição Constitucional Brasileira: Repercussão Geral, Força Vinculante, Modulação dos Efeitos do Controle de Constitucionalidade e Alargamento do Objeto do Controle Direto, São Paulo, Tese de Livre-Docência, USP., 2008. p. 25). 
Revista Eletrônica de Direito Processual - REDP.

Rio de Janeiro. Ano 11. Volume 18. Número 1. Janeiro a Abril de 2017

Periódico Quadrimestral da Pós-Graduação Stricto Sensu em Direito Processual da UERJ

Patrono: José Carlos Barbosa Moreira. ISSN 1982-7636. pp. 403-427

www.redp.uerj.br

Neste modo de julgamento por amostragem, ao julgar aquele recurso extraordinário com a repercussão geral, essa única decisão do STF deve ser multiplicada em todo o Brasil, afinal, este é o intuito da própria existência do instituto, propiciar à Suprema Corte que "escolha" as matérias relevantes para apreciar, com um efeito cascata para os demais casos.

Se, com a decisão positiva da admissibilidade daquele recurso extraordinário com repercussão geral, num primeiro momento, há uma suspensão nos demais processos idênticos, para quando ocorrer a decisão pelo STF neste regime de repercussão geral sobre a matéria, haver, de igual modo, impacto desta nos demais processos sobrestados existentes no próprio tribunal ou, ainda, represados nos tribunais anteriores.

O intuito da própria repercussão geral passa por prestar uma melhor atividade jurisdicional, com a análise superior para chegar-se somente a uma decisão, a qual definida, impactar todos os recursos que ficaram sobrestados para tal desiderato. Tal aplicabilidade da decisão proferida em regime de repercussão geral, com impacto aos recursos extraordinários sobrestados gera uma maior segurança jurídica, com a aplicabilidade de um único direito definido pelo STF.

Dessa maneira, não há necessidade de julgar todos os recursos em forma minimalista, ao definir a questão constitucional pela repercussão geral, numa análise mista entre caso concreto e aplicabilidade em abstrato, consegue um rumo material de decisão para aplicabilidade múltipla dessa decisão, aplicando nos processos sobrestados. $\mathrm{O}$ ganho processual do STF repassa pela ausência de julgamento caso a caso, suspendendo em um primeiro momento os processos para, após, aplicar uma decisão comum a todos, desafogando da análise pormenorizada dos tribunais, existente ou não uma multiplicidade de processos.

\subsection{A construção do efeito vinculativo da decisão de recurso extraordinário em regime de repercussão geral}

Uma grande questão sobre a repercussão geral recai na existência ou não de vinculação do que foi decidido pelo STF em recurso extraordinário. É uma questão pertinente, já que trata-se da Suprema Corte, o que, por si só, já serviria para criar tal vinculação ou autoridade para a criação de um precedente dessa magnitude. 
Revista Eletrônica de Direito Processual - REDP.

Rio de Janeiro. Ano 11. Volume 18. Número 1. Janeiro a Abril de 2017

Periódico Quadrimestral da Pós-Graduação Stricto Sensu em Direito Processual da UERJ

Patrono: José Carlos Barbosa Moreira. ISSN 1982-7636. pp. 403-427

www.redp.uerj.br

No entanto, se considerarmos o art. 927 do $\mathrm{CPC} / 2015$ como taxativo para as

espécies de decisões vinculantes, não encontraríamos ali, a decisão proferida pelo STF em tese definida em repercussão geral. Ou seja, na escolha legislativa processual, não há, claramente, vinculação da decisão recursal realizada via repercussão geral aos demais processos que tenham a mesma ratio decidendi.

Mas, esse raciocínio é correto? Entendemos que não. Primeiro, pelo motivo do art. 927 não ser um rol exaustivo de decisões vinculantes, mas meramente exemplificativo ${ }^{21}$, o que possibilita que outras espécies que não encontram-se ali delineadas também podem ter o grau de vinculação, pela conjunção de outras normas e a pela própria escolha legislativa.

Depois, pela conjunção existente na redação do art. 1.030 e do art. 1.042, permitindo perceber que o legislador inseriu a necessidade de seguir os precedentes criados a partir de julgamentos de recursos extraordinários dotados de repercussão geral, ainda que não tenha incluído no rol do art. 927, como precedente legalmente vinculante.

\subsubsection{A construção do efeito vinculativo sobre os recursos sobrestados no STF}

$\mathrm{O}$ art. 1.036, $\S 5^{\circ}$ determina que, uma vez reconhecida a existência de repercussão geral - independentemente de multiplicidade - todos os processos de igual matéria devem ser suspensos ${ }^{22}$. Logo, a razoabilidade recai no pensamento de que há uma cautela para que estes processos não sejam decididos enquanto o STF não fixar entendimento sobre a questão, o que, consequentemente, vinculará quando assim fizer.

$21 \quad$ "O rol do art. 927 é meramente exemplificativo, devendo os tribunais concretizá-lo em conformidade à Constituição Federal, que resguarda o princípio da segurança jurídica, da igualdade e da eficiência, todos eles plenamente aplicáveis à atividade jurisdicional. Realmente, não se concebe que possa um juiz de primeiro grau julgar em desconformidade a um precedente do STF em recurso extraordinário sem fazer uma distinção." MACEDO Lucas Buril de. Precedentes judiciais: como podemos sentir falta do que nunca tivemos http://justificando.com/2015/05/06/os-precedentes-judiciais-no-cpc2015-ou-de-comopodemos-sentir-falta-do-que-nunca-tivemos/

22 Em sentido contrário, Cunha e Didier Jr entendem que a suspensão somente seria para recursos que fossem aceitos como repetitivos, posição que entendo que não há pertinência, até pela visualização quantificativa do que seria essa repetição e, ainda, a regra está disposta tanto na repercussão geral quanto nos repetitivos, o que importa em técnicas suspensivas parecidas, contudo diversas: "A regra aplica-se exclusivamente aos casos em que a repercussão geral será julgada pela técnica dos recursos extraordinários repetitivos" CUNHA, Leonardo José Carneiro da; DIDIER JR., Fredie. Curso de direito processual civil. Meios de impugnação às decisões judiciais e processo nos tribunais. 13ª ed. Salvador: JusPodivm, 2016. p. 374. 
Revista Eletrônica de Direito Processual - REDP.

Rio de Janeiro. Ano 11. Volume 18. Número 1. Janeiro a Abril de 2017

Periódico Quadrimestral da Pós-Graduação Stricto Sensu em Direito Processual da UERJ

Patrono: José Carlos Barbosa Moreira. ISSN 1982-7636. pp. 403-427

www.redp.uerj.br

Uma vez decidida a questão constitucional em regime de repercussão geral, os demais recursos, outrora sobrestados, sofrem o impacto deste entendimento jurídico firmado, como já imaginava José Henrique Araújo Mouta ${ }^{23}$.

Essa vinculação aos recursos sobrestados causa um efeito cascata, primeiramente, dentro do próprio STF, quando serão julgados pelos seus relatores, aplicando o conteúdo da decisão proferida por amostragem. Se o recurso extraordinário contém pedido no mesmo sentido da decisão proferida, deve ser julgado provido. Por outro lado, se a decisão recorrida tinha o mesmo entendimento da questão jurídica decidida e firmada pelo STF e, consequentemente, o recurso tem pedido contrário à decisão, deve ser julgado prejudicado, pela aplicação da decisão paradigma amostrada.

A vinculação sobre a qual o próprio STF deve julgar os recursos sobrestados mediante a orientação realizada em regime de repercussão geral, ganha o nome de horizontal, quando o próprio tribunal que firmou o precedente, deve segui-lo.

No caso do não reconhecimento da repercussão geral, há uma vinculação latente e notória, exposta no próprio art. 1.036, $\S 8^{\circ}$ quando dispõe que "negada a repercussão geral, o presidente ou o vice-presidente do tribunal de origem negará seguimento aos recursos extraordinários sobrestados na origem que versem sobre matéria idêntica."

Esse impacto negativo é uma vinculação da decisão ali criada de que aquela matéria não tem repercussão geral e, assim, não comporta julgamento pelo STF. Em consequência, $\operatorname{todos}^{24}$ os outros recursos extraordinários que versem sobre a mesma questão, não terão a repercussão geral, importante em uma evidente inadmissibilidade ${ }^{25}$.

Numa construção doutrinária, se o não reconhecimento da repercussão geral atinge todos os recursos de matéria idêntica, logo, em sentido contrário, a decisão que admitir a repercussão geral, possibilitando o julgamento meritório daquele recurso extraordinário,

\footnotetext{
23 "De mais a mais, a decisão do STF, ao interpretar a questão constitucional concreta será vinculante, devendo ser aplicada pelos demais tribunais nacionais e pelos próprios ministros relatores, em casos repetidos." ARAUJO, José Henrique Mouta. O julgamento dos recursos especiais por amostragem: notas sobre o art. 543-C do CPC. Revista Dialética de Direito Processual n. 65, São Paulo : Dialética: p. 55/62. ago/2008, p.55

$24 \quad$ "eficácia futura, pois todos os casos idênticos de Recursos Extraordinários deverão ser liminarmente indeferidos." CRUZ E TUCCI, José Rogério. Anotações sobre a repercussão geral como pressuposto de admissibilidade do Recurso Extraordinário (Lei no 11.418/2006), in Revista do Advogado, no 92, 2007. p. 29 25 "Vê-se, assim, que a decisão do STF tem caráter absolutamente vinculante, quanto à inadmissibilidade do recurso em razão da ausência de repercussão geral. Deverá o órgão a quo, assim, ater-se ao que tiver deliberado o STF a respeito." WAMBIER, Teresa Arruda Alvim. Recurso Extraordinário e Ação Rescisória. $2^{\mathrm{a}}$ ed., São Paulo, RT, 2008. p.305/306.
} 
Revista Eletrônica de Direito Processual - REDP.

Rio de Janeiro. Ano 11. Volume 18. Número 1. Janeiro a Abril de 2017

Periódico Quadrimestral da Pós-Graduação Stricto Sensu em Direito Processual da UERJ

Patrono: José Carlos Barbosa Moreira. ISSN 1982-7636. pp. 403-427

www.redp.uerj.br

deve, de igual maneira, vincular-se aos recursos sobrestados e idênticos, seja pelo reconhecimento da matéria, bem como do resultado futuro do mérito daquele recurso paradigma pelo STF.

\subsection{O efeito vinculativo da decisão de mérito em regime de repercussão geral nos recursos em tribunais anteriores}

O mesmo impacto realizado internamente no STF, aos recursos sobrestados, acontece nos tribunais anteriores que também tem recursos extraordinários para serem tramitados, o que Marinoni e Mitidiero denominam como vinculação vertical ${ }^{26}$.

Se o acórdão recorrido, deste recurso sobrestado, coincidir com a decisão da repercussão geral, o presidente do tribunal recorrido deve negar seguimento ao recurso, com a impossibilidade de recurso desta decisão. Se o acórdão recorrido for em sentido diverso da decisão do STF, o presidente daquele tribunal devolve o processo para o órgão fracionário que decidiu daquela maneira, para reexame sobre a matéria, entre o que o acórdão decidiu e a decisão do tribunal superior.

Entretanto, essa adequação, a qual chegamos pela conjunção do art. 1.030 e do 1.042 resulta numa real vinculação legal? Essa é a grande questão, o tribunal anterior seja o STJ ou aqueles de segundo grau - devem seguir, obrigatoriamente, a decisão de mérito do recurso extraordinário paradigma decidido em regime de repercussão geral? A construção visualizada neste trabalho opta pela existência de uma vinculação legal, com a demonstração de que a conjunção destes artigos acima mencionados, cominados com o art. 1.035, o qual o CPC/2015 remodela a repercussão geral, obrigam os tribunais anteriores a seguirem o decidido pelo STF em regime de repercussão geral, atribuindo um efeito híbrido, o que Dinamarco chamaria de capacidade expansiva ${ }^{27}$.

\footnotetext{
26 "A rigor, se houver clara identificação da ratio decidendi utilizada pelo Supremo Tribunal Federal para o julgamento de mérito da questão a ele apresentada, há mesmo vinculação jurídica, em sentido vertical, dos Tribunais de origem, à decisão do Supremo. A jurisprudência do Supremo Tribunal Federal é, aliás, de há muito nesse sentido." MARINONI, Luis Guilherme; MITIDIERO, Daniel. Repercussão Geral no Recurso Extraordinário. $2^{\text {a }}$ ed., São Paulo, RT, 2008. p. 64

27 "mirando o exemplo da Corte Suprema norte-americana, quer agora a Constituição que também a nossa Corte só se ocupe de casos de interesse geral, cuja decisão não se confine à esfera de direito exclusivamente dos litigantes e possa ser útil a grupos inteiros ou a uma grande quantidade de pessoas." DINAMARCO, Candido Rangel. O processo civil na reforma constitucional do Poder Judiciário, in Reforma do Judiciário - Comentários à Emenda Constitucional no 45/2004, Sérgio Rabello Tamm Renault Pierpaolo Bottini (coords.)., São Paulo, Saraiva, 2.005. p. 300-301
} 
Revista Eletrônica de Direito Processual - REDP.

Rio de Janeiro. Ano 11. Volume 18. Número 1. Janeiro a Abril de 2017

Periódico Quadrimestral da Pós-Graduação Stricto Sensu em Direito Processual da UERJ

Patrono: José Carlos Barbosa Moreira. ISSN 1982-7636. pp. 403-427

www.redp.uerj.br

Esta vinculação, com a impossibilidade de recurso extraordinário seguir ao STF se opta por pleitear matéria contrária ao que já se estabeleceu em regime de repercussão geral, impõe a própria Suprema Corte a atuar como uma corte necessariamente de precedentes ${ }^{28}$. Nesta visão, a decisão do mérito do recurso extraordinário em regime de repercussão geral tem uma notória vinculação, ainda que limitada e que não esteja contida no rol dos precedentes obrigatórios elencados no art. 927, mas pela conjunção dos outros dispositivos legais cominados e citados acima.

\subsubsection{O novo art. 1.030 e a vinculação como precedente: negativa de seguimento ou juízo de retratação}

Para se chegar que há uma vinculação - dos recursos já existentes e os futuros sobre o julgamento em recurso extraordinário com repercussão geral reconhecida, utilizamos, primeiramente, a base do art. 1.030, I, quando dispõe que "negar seguimento: a) (...) a recurso extraordinário interposto contra acórdão que esteja em conformidade com entendimento do Supremo Tribunal Federal exarado no regime de repercussão geral; (Incluído pela Lei n ${ }^{\circ} 13.256$, de 2016)."

A alínea A disposta acima especifica que o presidente ou vice-presidente do tribunal recorrido, quando em análise do filtro de admissibilidade prévia, se constatar que o pleito existente naquele recurso extraordinário interposto for baseado materialmente contra entendimento firmado pelo STF em regime de repercussão geral, deve ser negada a admissibilidade ${ }^{29}$.

O intuito é explicitar ao recorrente que o pleito material recursal que pretende não tem razão de existir, por ir contra um precedente firmado pelo STF em processo com a mesma ratio decidendi, não necessitando a remessa ao tribunal superior, justamente por ir contra uma matéria definida em repercussão geral, estando, assim, o acórdão do tribunal

28 "Ora,a função da Corte Suprema, mais do que evitar decisões diferentes para casos em que se repetem em massa, dirige-se a casos que abrem oportunidade para a orientação da sociedade mediante a instituição de precedentes." MARINONI, Luiz Guilherme. A função das cortes supremas e o novo cpc. Revista Magister de Direito Civil e Processual Civil n. 65 - Mar/Abr/2015. p. 21

29 "A segunda hipótese é o recurso extraordinário interposto contra acórdão que esteja em conformidade com o entendimento do Supremo Tribunal Federal exarada no regime de repercussão geral. Ainda que tal julgamento tenha eficácia vinculante erga omnes, entendo que nesse caso a questão é de mérito, somente sendo tratada como sendo de admissibilidade para permitir que o recurso seja inadmitido em segundo grau." NEVES, Daniel Amorim Assumpção. Novo Código de Processo Civil - Lei 13.105/2015. Salvador: Jus Podivm, 2016, 2245/2246 
Revista Eletrônica de Direito Processual - REDP.

Rio de Janeiro. Ano 11. Volume 18. Número 1. Janeiro a Abril de 2017

Periódico Quadrimestral da Pós-Graduação Stricto Sensu em Direito Processual da UERJ

Patrono: José Carlos Barbosa Moreira. ISSN 1982-7636. pp. 403-427

www.redp.uerj.br

recorrido condizente com o precedente existente, não merecendo reparo, pelo fato da argumentação recursal ser negar somente ser contrário ao precedente firmado.

Para que o recorrente tenha chance no seu pleito contra um acórdão embasado em um precedente oriundo de julgamento do STF em repercussão geral, deve trazer subsídios de distinção, para explicação ao próprio tribunal superior que houve enquadramento equivocado de sua matéria na questão ali definida como aplicável do precedente ou, ainda, trazer um ônus argumentativo de revisão de tese para o que se decidiu no STF, o que ensejaria novos fundamentos, pleiteando uma superação de um precedente.

Sem qualquer um destes argumentos recursais - distinção ou superação - e, se realmente houver a identidade entre o caso recorrido e a ratio decidendi do precedente do STF em regime de repercussão geral, o recurso extraordinário deve ser pela inadmissibilidade, com uma decisão proferida pelo presidente ou vice-presidente neste sentido, negando seguimento.

Outro ponto pertinente sobre vinculação que retira-se do art. 1.030 está na inciso II, quando dispõe que o presidente ou vice-presidente, ao analisar o recurso extraordinário, deve "encaminhar o processo ao órgão julgador para realização do juízo de retratação, se o acórdão recorrido divergir do entendimento do Supremo Tribunal Federal ou do Superior Tribunal de Justiça exarado, conforme o caso, nos regimes de repercussão geral.”

Ou seja, se, realizada a análise do recurso extraordinário, verificar-se que o ato recursal utiliza como base argumentativa a existência de julgado do STF em regime de repercussão geral e que o acórdão impugnado que não segue o que se definiu em grau superior, deve ser possibilitada ao colegiado, em juízo de retratação, que verifique a existência de precedente de tal autoridade, com a plena possibilidade de reanálise para a aplicabilidade do precedente ali invocado ${ }^{30}$.

Dessa maneira, se o acórdão não seguir a orientação do STF em regime de repercussão geral e, houver um recurso extraordinário, ao invés deste ir diretamente ao tribunal superior, o presidente ou vice-presidente encaminha novamente para a turma, com

$30 \quad$ O dispositivo permite a conclusão de que na hipótese de possível retratação pelo órgão julgador não cabe ao presidente ou vice-presidente do tribunal de segundo grau analisar a admissibilidade do recurso, conclusão corroborada pela alínea "a" do inciso V do art. 1.030 do Novo CPC, que prevê a realização do juízo de admissibilidade somente se o recurso não tiver sido submetido ao regime de julgamento de recursos repetitivos. NEVES, Daniel Amorim Assumpção. Novo Código de Processo Civil - Lei 13.105/2015. Salvador: Jus Podivm, 2016, p. 2246 
Revista Eletrônica de Direito Processual - REDP.

Rio de Janeiro. Ano 11. Volume 18. Número 1. Janeiro a Abril de 2017

Periódico Quadrimestral da Pós-Graduação Stricto Sensu em Direito Processual da UERJ

Patrono: José Carlos Barbosa Moreira. ISSN 1982-7636. pp. 403-427

www.redp.uerj.br

a disposição de que utilize o precedente ali citado e não superado pela turma em ônus argumentativo.

Pode-se argumentar que o órgão que proferiu o acórdão pode manter a sua decisão, refutando o juízo de retratação, ensejando uma não vinculação do precedente do STF em regime de repercussão geral, contudo, nesta hipótese, com base no art. 1.030, IV, alínea C, o presidente ou vice-presidente deve optar pela admissibilidade positiva do recurso extraordinário interposto, remetendo-o a Suprema Corte, para que lá se verifique a aplicabilidade do precedente ou eventual flexibilização, com possível superação ou distinção ${ }^{31}$.

\subsubsection{O art. 1.042 e a impossibilidade de agravo em RE contrário ao entendimento firmado em repercussão geral}

Outro ponto que permite a construção de uma vinculação do precedente criado em regime de repercussão geral está no art. 1.042, quando dispõe que a decisão do presidente ou vice-presidente proferida em juízo prévio de admissibilidade, pela negativa de recurso extraordinário, baseando-se que o acórdão recorrido fundou-se na aplicação correta do entendimento firmado em regime de repercussão geral, não caberá agravo para levar este recurso excepcional ao STF.

Desse modo, se o presidente ou vice-presidente entender que o tribunal recorrido utilizou corretamente, no acórdão recorrido, a tese firmada em julgamento em regime de repercussão geral e, este recurso extraordinário não trouxer nenhum pedido de revisão de tese ou distinção, além de inadmiti-lo, advertirá o recorrente que, dessa decisão, não caberá recurso ao STF.

$\mathrm{O}$ art. 1.042, nesta leitura, concede ao precedente firmado em regime de repercussão geral uma autoridade imensa, com a impossibilidade de recurso extraordinário

31 “A posição assumida pelo Supremo Tribunal em julgamento destinado precisamente a pautar uma pluralidade de recursos (portanto, uma decisão que se pode supor adotada com adicional prudência), se não vincula estritamente, é fortíssimo argumento de autoridade. Some-se a isso a imposição de razoabilidade: se a decisão não for objeto de retratação, será revista depois pelo próprio STF. Daí que, ainda que o órgão prolator da decisão recorrida tenha a possibilidade de não se retratar, apenas deverá seguir por essa senda se reputar que o caso posto para o exame reveste-se de peculiaridades que não autorizam submetê-lo à decisão quadro, ou, ainda, se entender que dispõe de argumentos que não foram considerados no julgamento do recursoamostra" TALAMINI, Eduardo. Novos Aspectos da Jurisdição Constitucional Brasileira: Repercussão Geral, Força Vinculante, Modulação dos Efeitos do Controle de Constitucionalidade e Alargamento do Objeto do Controle Direto, São Paulo, Tese de Livre-Docência, USP, 2008. p. 76/77 
Revista Eletrônica de Direito Processual - REDP.

Rio de Janeiro. Ano 11. Volume 18. Número 1. Janeiro a Abril de 2017

Periódico Quadrimestral da Pós-Graduação Stricto Sensu em Direito Processual da UERJ

Patrono: José Carlos Barbosa Moreira. ISSN 1982-7636. pp. 403-427

www.redp.uerj.br

demonstrar mero inconformismo com a decisão do tribunal recorrido, necessitando, quando confrontar precedente de autoridade em repercussão geral, que o distingua ou supere, o que, sem fazê-lo, nem poderá interpor agravo para destrancar o recurso.

E, ainda, se o presidente entender que o precedente foi bem utilizado pelo tribunal recorrido, com o devido enquadramento, mesmo que o recorrente queira a revisão de tese ou distinção, o agravo do art. 1.042 não será o meio adequado, optando o legislador por incluir o agravo interno dessa decisão, o que, mesmo assim, deve versar sobre distinção ou superação, não podendo, de igual maneira, versar somente sobre mero inconformismo.

Nesta conjunção, se o tribunal - de segundo grau ou o STJ - aplicar corretamente o precedente firmado em regime de repercussão geral, o recurso extraordinário deve ter negado a sua admissibilidade, com a impossibilidade de recurso sobre tal decisão - se for calcado em mero inconformismo - o que leva a construção de que este precedente tem um alto grau de vinculação, impossibilitando recurso para o tribunal superior quando a sua aplicabilidade for correta.

\subsection{O efeito sob a matéria para os recursos vindouros}

Se a vinculação proposta pela construção de uma legalidade desta via art. 1.030 e 1.042 impacta os recursos extraordinários já existentes, de igual maneira, deve vincular a matéria decidida em regime de repercussão geral para qualquer outro julgamento ulterior. Se, após a decisão do STF, com a definição do mérito daquela matéria sobre a qual foi reconhecida a repercussão geral, algum tribunal - o STJ ou tribunais de segundo grau insistirem em decidir de maneira contrária ao definido em precedente pela Suprema Corte, o possível recurso extraordinário futuro deve ser encaminhado, como já vimos, no art. 1.030, II, para que o colegiado recorrido realize o juízo de retratação.

Ora, na hipótese de algum colegiado de tribunal não seguir o que o STF determinou em matéria julgada em regime de repercussão geral, o presidente do tribunal recorrido devolve para um juízo regressivo, com a evidente orientação de que siga aquilo que determinado como precedente. Caso, ainda assim, não siga o precedente firmado em regime de repercussão geral, o presidente do tribunal admitirá o recurso extraordinário, pelo fato de não ter competência para manifestar-se sobre o mérito recursal, cabendo ao 
Revista Eletrônica de Direito Processual - REDP.

Rio de Janeiro. Ano 11. Volume 18. Número 1. Janeiro a Abril de 2017

Periódico Quadrimestral da Pós-Graduação Stricto Sensu em Direito Processual da UERJ

Patrono: José Carlos Barbosa Moreira. ISSN 1982-7636. pp. 403-427

www.redp.uerj.br

STF, ao recepcionar tal recurso, somente aplicar o precedente criado anteriormente, podendo fazê-lo monocraticamente.

De modo diverso, se o acórdão do tribunal anterior aplicar o que o STF determinou em regime de repercussão geral, o eventual recurso extraordinário também será negado em sua admissibilidade pelo presidente ou vice-presidente do tribunal recorrido, demonstrando que o acórdão segue o precedente de maneira correta, impondo, ali, que uma vinculação da utilização da decisão realizada em sede de repercussão geral, num controle, pelo próprio tribunal recorrido, da aplicabilidade correta do precedente, sobre o qual, inadmite recurso extraordinário.

No entanto, cabe a diferenciação desta vinculação futura daquele proveniente dos recursos sobrestados para o julgamento do mérito da repercussão geral, nestes últimos a vinculação decorre da própria suspensão - com ou sem multiplicidade - pelo reconhecimento da repercussão e a espera para a definição material de seu julgamento. Já a vinculação futura passa pelo aspecto de eficácia futura da própria decisão, a qual tem uma valoração argumentativa e, consequentemente, vinculativa, por ser do $\mathrm{STF}^{32}$ e, também, por ser em regime de repercussão geral.

\subsection{A opção do legislador no CPC/2015 pela não vinculação legal no art. 927}

Se todos estes argumentos de construção interpretativa e pela conjunção dos art. 1.030 e 1.042 primam pela vinculação, aos recursos sobrestados e como precedente judicial, por qual motivo o acórdão proferido em regime de repercussão geral em recurso extraordinário não entra no rol do art. 927, dos precedentes obrigatórios? Essa é uma das grandes questões do sistema de precedentes.

O primeiro ponto passa pela existência da vinculação da atividade do STF ser realizada, mesmo em sede de repercussão geral, tanto pelas turmas, quanto pelo pleno, o

\footnotetext{
32 "Boa parte desses precedentes obrigatórios advém de julgamento de recurso extraordinário. O recurso extraordinário passa a servir como um instrumento para a solução do caso do recorrente e para a definição do precedente obrigatório sobre a questão constitucional nele versada. Como o recurso extraordinário é o principal instrumento do controle difuso de constitucionalidade, os precedentes do Pleno do STF em tais casos passam a ter eficácia obrigatória, transcendendo os limites subjetivos da causa da qual surgiu. A solução do caso vale apenas para as partes (coisa julgada, art. 506 do CPC); mas o precedente tem eficácia erga omnes.” CUNHA, Leonardo José Carneiro da; DIDIER JR., Fredie. Curso de direito processual civil. Meios de impugnação às decisões judiciais e processo nos tribunais. $13^{\mathrm{a}}$ ed. Salvador: JusPodivm, 2016. p. 376.
} 
Revista Eletrônica de Direito Processual - REDP.

Rio de Janeiro. Ano 11. Volume 18. Número 1. Janeiro a Abril de 2017

Periódico Quadrimestral da Pós-Graduação Stricto Sensu em Direito Processual da UERJ

Patrono: José Carlos Barbosa Moreira. ISSN 1982-7636. pp. 403-427

www.redp.uerj.br

que, na primeira hipótese, talvez, o regime de repercussão geral não seria realmente vinculante, já que não representaria o que a Corte entende naquela matéria. Este é um ponto chave para o questionamento contrário à vinculação da repercussão geral, o qual, de igual forma, mesmo entendendo pela vinculação, construímos que não há como entender que a decisão de uma turma do STF vincule. Neste ínterim, pertinente pensar se as turmas deveriam julgar recurso extraordinário em repercussão geral? Com os milhares de recursos extraordinários interpostos, o pleno conseguiria sanar todas as matérias? São questões pertinentes e que demonstram que somente a repercussão geral utilizada pelas turmas, não traz a capacidade máxima do instituto, com muitas vezes, o julgamento, mesmo em repercussão geral, pelas turmas de maneira divergente, o que permite o cabimento de embargos de divergência.

Outro ponto que inviabilizou a inserção do entendimento em regime de repercussão geral ser visualizado de forma obrigatória seria igualar este à própria súmula vinculante ${ }^{\mathbf{3 3}}$, o que, de certa maneira, seria acabar com o instituto constitucional vinculante. Se todos os julgamentos oriundos de recursos extraordinários em regime de repercussão geral fossem imbuídos de vinculação obrigatória, não necessitaria da edição de súmula vinculante, quiça nem de súmulas, já que o próprio recurso extraordinário permitiria a vinculação automática de suas teses.

Esses são dois pontos argumentativos para que não houvesse a inserção do regime de repercussão geral como precedente obrigatório quando julgado seu mérito, ainda que entendemos que o funcionamento da Corte Suprema devesse ser remodelado para fins de maior vinculação e autoridade do próprio julgamento dos recursos extraordinários em repercussão geral. Uma pena não ter esse avanço ${ }^{34}$.

\footnotetext{
33 "Daí falar em repercussão geral - e não porque toda decisão que vier a ser tomada em recurso extraordinário vincule todos, com eficácia ou autoridade erga omnes, mas porque certamente exercerá influência em julgamentos futuros e poderá até abrir caminho para a edição de uma súmula vinculante." DINAMARCO, Cândido Rangel. O processo civil na reforma constitucional do Poder Judiciário, in Reforma do Judiciário - Comentários à Emenda Constitucional no 45/2004, Sérgio Rabello Tamm Renault Pierpaolo Bottini (coords.)., São Paulo, Saraiva, 2005. p.300-301

34 "Na lista de decisões que devem ser seguidas, a mais expressiva previsão foi simplesmente excluída: não se vê determinação de que os tribunais sigam os precedentes do STF em matéria constitucional, mas apenas as decisões em controle concentrado de constitucionalidade." MACEDO, Lucas Buril de. Precedentes judiciais: como podemos sentir falta do que nunca tivemos. http://justificando.com/2015/05/06/os-precedentes-judiciais-no-cpc2015-ou-de-como-podemos-sentir-faltado-que-nunca-tivemos/
} 
Revista Eletrônica de Direito Processual - REDP.

Rio de Janeiro. Ano 11. Volume 18. Número 1. Janeiro a Abril de 2017

Periódico Quadrimestral da Pós-Graduação Stricto Sensu em Direito Processual da UERJ

Patrono: José Carlos Barbosa Moreira. ISSN 1982-7636. pp. 403-427

www.redp.uerj.br

\subsubsection{O argumento de autoridade da decisão de mérito em repercussão geral}

Mesmo sem uma vinculação obrigatória e legal, construindo doutrinariamente um sentido de legalidade de obrigatoriedade via a conjunção dos art. 1.030 e 1.042, o decidido em sede de repercussão geral tem uma autoridade enquanto precedente, o que entendemos como vinculativo, se realizado pelo pleno e, somente persuasivo, se realizado pela turma, construindo uma diferenciação entre os julgados oriundos do próprio instituto, fato que já expusemos como nocivo para a própria Corte, que deveria ater-se, enquanto plenário, à análise do mérito da repercussão geral.

\subsubsection{Decisão de mérito proferida pelo pleno}

Se a decisão do recurso extraordinário em regime de repercussão geral for proferido pelo pleno do STF, há uma sedimentação do entendimento, produzindo, dessa maneira, o precedente da própria Suprema Corte, a qual, naquela ratio decidendi, entendemos que haja uma vinculação obrigatória aos recursos eventualmente sobrestados, em regime de repetitivo ou não, aos recursos já interpostos e não sobrestados e, por aplicação obrigatória de precedente, a todos os tribunais anteriores quando futuramente forem julgar processos e recursos sobre a mesma matéria.

A decisão oriunda do pleno do STF detém, por si só, uma argumentação imensa de capacidade vinculativa, mesmo sem estar inserta ao art. 927 e aquele rol, o qual entendemos como exemplificativo.

Nesta visualização, temos duas situações: a primeira, a evidente vinculação sobre os recursos sobrestados; a segunda, a obrigatoriedade de utilização como precedente em casos futuros. Em ambas, entendemos que o julgamento de recurso extraordinário em regime de repercussão geral pelo pleno, tem, pela conjuntura proposta pelos art. $1.030 \mathrm{e}$ 1.042, uma eficácia vinculante.

Se o art. 1.030 entende que é eivado de latente inadmissibilidade um recurso que impugna acórdão que segue orientação firmada em regime de repercussão geral, a obrigatoriedade de seguir o entendimento está ali positivado e, aqui, tanto faz se para os recursos outrora sobrestados ou nos futuros, quando sobrevier a aplicação de um precedente e não de tese jurídica. 
Revista Eletrônica de Direito Processual - REDP.

Rio de Janeiro. Ano 11. Volume 18. Número 1. Janeiro a Abril de 2017

Periódico Quadrimestral da Pós-Graduação Stricto Sensu em Direito Processual da UERJ

Patrono: José Carlos Barbosa Moreira. ISSN 1982-7636. pp. 403-427

www.redp.uerj.br

Mesmo resultado chegamos quando, pela leitura do art. 1.042, quando o presidente ou vice-presidente do tribunal recorrido proferir a inadmissibilidade disposta no art. 1.030, pelo fato do recurso extraordinário atentar contra acórdão baseado em regime de repercussão geral, desta decisão monocrática, não caberá o agravo para levar ao STF, o que importa numa autêntica vinculação, obstando a revisão por mero inconformismo, justamente por atentar contra um precedente firmado em recurso extraordinário em regime de repercussão geral.

\subsubsection{Decisão de mérito proferida por turma}

A dúvida, como já expusemos, está quando a decisão do STF em regime de repercussão geral é firmada em decisão de mérito proferida por turma deste tribunal e, não pelo pleno. Nesta possibilidade, há vinculação? Analisemos, anteriormente, a conjunção do art. 1.030 e 1042 quando, ambos, dispõe sobre entendimento firmado em regime de repercussão, não diferenciando ali, se este foi proferido pelo pleno ou pela turma.

Entretanto, é difícil imaginar que, mesmo com a possibilidade da interpretação literal da norma, conceder o julgamento pela turma uma obrigatoriedade, não conseguindo esse efeito cascata, nem para os recursos eventualmente sobrestados, evidentemente sem repetição, já que se houver repetição, será realizado pelo plenário. Tampouco há como pensar que se firmará um precedente vinculante a casos futuros, se o STF julgou somente via turma, com isso, não firmando um entendimento que responda pela plenitude da Suprema Corte.

A saída passa pelo STF não julgar mais em regime de repercussão geral pela turma, até para que não haja divergência, prevenindo, desde já, entendimentos contrários. Cunha e Didier $\mathrm{Jr}^{35}$ entendem, acertadamente, como saída, que a turma utilize o incidente de assunção de competência, mesmo que não haja efetiva repetição de processos, transferindo a competência para o pleno e, criando, desde logo, um precedente vinculante.

35 “Assim, é preciso perceber as três situações possíveis: a) Recursos extraordinários repetitivos: a análise da repercussão geral será feita no contexto do julgamento dos recursos extraordinários repetitivos. b) Recurso extraordinário não repetitivo julgado pela turma: reconhecida a repercussão geral, a turma julgará o recurso. c) Recurso extraordinário não repetitivo julgado pelo Plenário: reconhecida a repercussão geral, a turma pode afetar o caso para julgamento pelo Plenário, instaurando o incidente de assunção de competência." CUNHA, Leonardo José Carneiro da; DIDIER JR., Fredie. Curso de direito processual civil. Meios de impugnação às decisões judiciais e processo nos tribunais. 13 ${ }^{\mathrm{a}}$ ed. Salvador: JusPodivm, 2016. p. $371 / 372$ 
Revista Eletrônica de Direito Processual - REDP.

Rio de Janeiro. Ano 11. Volume 18. Número 1. Janeiro a Abril de 2017

Periódico Quadrimestral da Pós-Graduação Stricto Sensu em Direito Processual da UERJ

Patrono: José Carlos Barbosa Moreira. ISSN 1982-7636. pp. 403-427

www.redp.uerj.br

O intuito é julgar os casos em que se analisa a repercussão geral sem multiplicidade e recursos repetitivos também somente pelo pleno, deixando cada vez mais, a competência das turmas para as ações de competência originário - que nada guardam relação com a repercussão geral - e as análises posteriores à decisão de repercussão geral e os eventuais recursos futuros, seja agravos internos contra as decisões monocráticas, ou, ainda, os eventuais recursos extraordinários que sejam admitidos na origem por não seguirem o que se definiu em regime de repercussão geral.

Dessa maneira, apesar de defender a vinculação obrigatória - aos recursos sobrestados ou como precedente judicial - do entendimento firmado em repercussão geral, construo a ressalva de que somente deve ser utilizado quando julgado pelo pleno do STF.

A decisão em recurso extraordinário em regime de repercussão geral proferida somente por turma do STF detém uma autoridade persuasiva argumentativa imensa, contudo, sem a vinculação.

\section{A FUNÇÃO DO STF, A REPERCUSSÃO GERAL E A NECESSÁRIA CULTURA DE PRECEDENTE}

A repercussão geral é elemento base do recurso extraordinário desde a sua regulamentação na década passada, com a visualização de que somente recursos com tal transcendência devem ser apreciados como temas pertinentes à análise da Suprema Corte. É, ao mesmo tempo, filtro de relevância de natureza processual, quanto de natureza política, possibilitando ao STF que "escolha" o que entende como pertinente para debruçar-se em julgamento.

Dessa maneira, se há uma definição proferida pelo STF de que não se debruçará sobre questão específica, ainda que seja constitucional, por esta não conter repercussão geral, consequentemente, todos os processos e recursos daquela matéria não serão apreciados $^{36}$. Contudo, em sentido inverso, se o recorrente conseguir demonstrar que o seu recurso ultrapassa os interesses inter partes - social, econômica, política ou juridicamente, este será julgado, justamente por importar além de sua própria limitação processual, com

36 Comentário do autor: salvo, evidentemente, revisão de tese com novos argumentos impossíveis ou não analisados na época da decisão de admissibilidade do tribunal superior. 
Revista Eletrônica de Direito Processual - REDP.

Rio de Janeiro. Ano 11. Volume 18. Número 1. Janeiro a Abril de 2017

Periódico Quadrimestral da Pós-Graduação Stricto Sensu em Direito Processual da UERJ

Patrono: José Carlos Barbosa Moreira. ISSN 1982-7636. pp. 403-427

www.redp.uerj.br

aplicabilidade para outras demandas ou para a própria sociedade, pela importância ali demonstrada.

Com essa possibilidade de escolha, o STF, cada dia mais, deve assumir o seu papel enquanto Corte de Precedentes, julgando menos e impactando mais a sociedade, o que, de certa maneira, a repercussão geral obteve êxito em seu desiderato. Todavia, o CPC/2015 pouco avançou sobre a eficácia ${ }^{37}$ da decisão proferida em repercussão geral, deixando a questão constitucional ali decidida no recurso extraordinário com menor eficácia do que o decidido se o caso for repetitivo.

Logo, uma decisão do STF, em regime de repercussão, pelo rol do art. 927, se considerar-se como taxativo, não vincularia ${ }^{38}$ o próprio STF, bem como os tribunais e juízos anteriores. Uma pena esta lacuna na legislação, por mais que seja uma opção do legislador. No entanto, uma decisão da Corte Constitucional, pela própria função do STF deve ser eivada, quando proferida pelo seu pleno, de caráter obrigatório, seja pela autoridade de órgão máximo do judiciário, seja pelo controle ali realizado sobre a matéria constitucional.

Para a construção de tal pensamento vinculativo, há de se conseguir a conjunção de alguns pontos: definir que tal a decisão seja proferida pelo plenário; o STF entenda cada vez mais sua função de Corte de precedentes; a visualização do recurso extraordinário como uma excepcionalidade para se criar paradigmas.

A utilização do requisito de admissibilidade da repercussão geral não pode somente ser um filtro da admissibilidade por relevância, mas, o próprio CPC/2015, nas alterações provenientes da lei $\mathrm{n}^{0} .13 .256 / 2016$, com as novas redações dos art. 1.030 e 1.042, deu a deixa para que a decisão ali proferida tenha uma capacidade vinculante anda maior do que a prática a impõe, imputando a repercussão geral uma importância ainda maior do que a redação original imaginava.

\footnotetext{
37 Em sentido contrário, acreditando que não há como entender que a decisão proferida pelo STF fosse vinculante, contudo, ainda antes da Repercussão Geral: "Atribuir eficácia erga omnes a essa decisão recursal, ampliando a eficácia subjetiva da sentença, equivaleria a apagar da Constituição a garantia inscrita em seu art. $5^{\circ}$, incisos LIV, LV e XXXV. Isso é impossível sem ruptura da lei magna” CUNHA, Sérgio Sérvulo da. $O$ Efeito Vinculante e os Poderes do Juiz, São Paulo, Saraiva, 1.999, p. 30

38 "Falar-se em decisão de tribunal superior sem força vinculante é incidir-se em contradição manifesta. Seriam eles meros tribunais de apelação." CALMON DE PASSOS, J. J. Súmula vinculante, in Revista Eletrônica de Direito do Estado 9/9, http://www.direitodoestado.com.br/artigo/j-j-calmon-depassos/sumula-vinculante
} 
Revista Eletrônica de Direito Processual - REDP.

Rio de Janeiro. Ano 11. Volume 18. Número 1. Janeiro a Abril de 2017

Periódico Quadrimestral da Pós-Graduação Stricto Sensu em Direito Processual da UERJ

Patrono: José Carlos Barbosa Moreira. ISSN 1982-7636. pp. 403-427

www.redp.uerj.br

A decisão oriunda do plenário do STF em regime de repercussão geral tem caráter vinculativo, com total inserção no sistema ${ }^{39}$ de precedentes obrigatórios instituídos pelo novel ordenamento.

\section{REFERÊNCIAS BIBLIOGRÁFICAS}

ARAÚJO, José Henrique Mouta. A eficácia da decisão envolvendo a repercussão geral e os novos poderes dos relatores e dos tribunais locais. Revista de Processo, São Paulo, v. 32, n. 152, p. 185- 186, 2007.

O julgamento dos recursos especiais por amostragem: notas sobre o art. 543-

C do CPC. Revista Dialética de Direito Processual n. 65, São Paulo : Dialética: p. $55 / 62$. ago/2008

ASSUMPÇÃO, Hélcio Alves de. Recurso extraordinário: requisitos constitucionais de admissibilidade, in Meios de Impugnação ao Julgado Civil - estudos em homenagem a José Carlos Barbosa Moreira, Adroaldo Fabrício (coord.), Rio de Janeiro, Forense, 2007

BAPTISTA, N. Doreste. Da arguição de relevância no recurso extraordinário. Editora Forense, Rio de Janeiro. 1976.

BRASIL. Código de Processo Civil. Lei 13.105 de 16 de março de 2015. . Código de Processo Civil. Lei 5.869 de 11 de janeiro de 1973.

CALMON DE PASSOS, J. J. Súmula vinculante, in Revista Eletrônica de Direito do Estado 9/9, http://www.direitodoestado.com.br/artigo/j-j-calmon-de-passos/sumulavinculante

CÂMARA, Alexandre Freitas. Lições de Direito Processual Civil, volume II. 14a edição, Revista e atualizada. - Rio de janeiro: Editora Lúmen Júris, 2007.

\footnotetext{
39 “A consagração de um sistema de precedentes obrigatórios no Brasil (aparentemente inquestionável ao menos após o CPC-2o15, tal como examinado no v. 2 deste Curso) alterou o modo como se deve encarar o controle difuso de constitucionalidade das leis e, por consequência, a função do recurso extraordinário." CUNHA, Leonardo José Carneiro da; DIDIER JR., Fredie. Curso de direito processual civil. Meios de impugnação às decisões judiciais e processo nos tribunais. $13^{\mathrm{a}}$ ed. Salvador: JusPodivm, 2016. p. 376
} 
Revista Eletrônica de Direito Processual - REDP.

Rio de Janeiro. Ano 11. Volume 18. Número 1. Janeiro a Abril de 2017

Periódico Quadrimestral da Pós-Graduação Stricto Sensu em Direito Processual da UERJ

Patrono: José Carlos Barbosa Moreira. ISSN 1982-7636. pp. 403-427

www.redp.uerj.br

CRUZ E TUCCI, José Rogério. Anotações sobre a repercussão geral como pressuposto de admissibilidade do Recurso Extraordinário (Lei $\left.n^{o} 11.418 / 2006\right)$, in Revista do Advogado, n 92, 2007.

CUNHA, Leonardo José Carneiro da; DIDIER JR., Fredie. Curso de direito processual civil. Meios de impugnação às decisões judiciais e processo nos tribunais. $13^{\mathrm{a}}$ ed. Salvador: JusPodivm, 2016.

Curso de direito processual civil. Meios de impugnação às decisões judiciais e processo nos tribunais. $8^{\mathrm{a}}$ ed. Salvador: JusPodivm, 2012.

CUNHA, Sérgio Sérvulo da. O Efeito Vinculante e os Poderes do Juiz, São Paulo, Saraiva, 1999

DANTAS, Bruno. Repercussão geral: perspectivas histórica, dogmática e de direito comparado: questões processuais. São Paulo: Ed. Revista dos Tribunais, 2008.

DINAMARCO, Candido Rangel. O processo civil na reforma constitucional do Poder Judiciário, in Reforma do Judiciário - Comentários à Emenda Constitucional $\mathrm{n}^{\circ}$ 45/2004, Sérgio Rabello Tamm Renault - Pierpaolo Bottini (coords.)., São Paulo, Saraiva, 2005.

GOMES JR, Luiz Manoel. A Repercussão Geral da Questão Constitucional no Recurso Extraordinário. Revista Forense. 2005

LAMY, Eduardo de Avelar, Repercussão geral no recurso extraordinário: a volta da argüição de relevância?, in Reforma do Judiciário - primeiras reflexões sobre a Emenda Constitucional no 45/2004, coord. Teresa Arruda Alvim Wambier, São Paulo, RT, 2005.

MACEDO, Lucas Buril de. Precedentes judiciais: como podemos sentir falta do que nunca tivemos. http://justificando.com/2015/05/06/os-precedentes-judiciais-nocpc2015-ou-de-como-podemos-sentir-falta-do-que-nunca-tivemos/

MALTEZ, Rafael Tocantins, Repercussão geral da questão constitucional, in Recurso Especial e Extraordinário - repercussão geral e atualidades, Rogério Licastro Torres de Mello (coord.), São Paulo, Método, 2007. 
Revista Eletrônica de Direito Processual - REDP.

Rio de Janeiro. Ano 11. Volume 18. Número 1. Janeiro a Abril de 2017

Periódico Quadrimestral da Pós-Graduação Stricto Sensu em Direito Processual da UERJ

Patrono: José Carlos Barbosa Moreira. ISSN 1982-7636. pp. 403-427

www.redp.uerj.br

MARINONI, Luiz Guilherme. A função das cortes supremas e o novo cpc. Revista

Magister de Direito Civil e Processual Civil n. 65 - Mar/Abr/2015. p. 21

MARINONI, Luis Guilherme; MITIDIERO, Daniel. Repercussão Geral no Recurso Extraordinário, 2ª ed., São Paulo, RT, 2008.

MEDINA, José Miguel Garcia. Novo código de processo civil comentado. $4^{\mathrm{a}}$ Edição. RT: São Paulo. 2015.

MEDINA, José Miguel Garcia; WAMBIER, Luiz Rodrigues; WAMBIER, Teresa Arruda Alvim. Breves Comentários às Nova Sistemática Processual Civil 3. São Paula: Ed. Revista dos Tribunais, 2007.

NEVES, Daniel Amorim Assumpção. Novo Código de Processo Civil - Lei 13.105/2015. Salvador: Jus Podivm, 2016

OLIVEIRA, Pedro Miranda de. Recurso extraordinário e o requisito da repercussão geral. São Paulo: RT, 2013

TALAMINI, Eduardo. Novos Aspectos da Jurisdição Constitucional Brasileira: Repercussão Geral, Força Vinculante, Modulação dos Efeitos do Controle de Constitucionalidade e Alargamento do Objeto do Controle Direto, São Paulo, Tese de Livre-Docência), USP., 2008.

WAMBIER, Teresa Arruda Alvim. Recurso Extraordinário e Ação Rescisória, $2^{a}$ ed., São Paulo, RT, 2008. 